\title{
Evaluation of Patients Admitted to the Emergency Department of Kafkas University Faculty of Medicine Hospital due to Occupational Accidents
}

\author{
Murat ARAS (D) , Turgut DOLANBAY (iD) , Levent ŞAHIN
}

\begin{abstract}
Occupational accidents and illnesses are the most important problem in the business sector in all regions of the world, and about 160 million people are affected by occupational accidents annually worldwide. The evaluation of patients admitted to the emergency departments of hospitals due to occupational accidents is of special importance for reducing these accidents. In this study, patients admitted to the Emergency Department of Kafkas University Research and Training Hospital with occupational injuries were evaluated. It was observed that 38 patients applied to the emergency department because of occupational accidents between the specified dates. The mean age of these patients was $35.7 \pm 10.4$ years. It was determined that $40.5 \%$ of the patients had occupational accidents between 08:00-12:00. Most of the occupational accidents occurred on Monday and Saturday. Injuries of the upper extremity (28.95\%) and head/neck (28.95\%) were the most common injuries. Occupational accidents are common in the emergency department and play an important role in mortality and morbidity. First aid and occupational accident training should be provided to workers to prevent frequent accidents during working hours. We believe that due to the widespread of head/neck and upper extremity injuries, strict inspections of workers to ensure protective measures (such as clothing, gloves, helmets) will significantly reduce occupational accidents.
\end{abstract}

Keywords: Occupational Accidents, Trauma, Injury, Emergency Department

Murat ARAS | mrts_net@hotmail.com

Kafkas University, Faculty of Medicine, Department of Emergency Medicine, Kars, Turkey

Turgut DOLANBAY | turgutdolanbay@hotmail.com

Kafkas University Faculty of Medicine, Department of Emergency Medicine, Kars, Turkey

Levent ŞAHiN I levsahin44@gmail.com

Kafkas University, Faculty of Medicine, Department of Emergency Medicine, Kars, Turkey

Received/Geliş Tarihi : 24.04.2020 Accepted/Kabul Tarihi: 20.11.2020 


\section{INTRODUCTION}

Occupational accidents and illnesses are the most important problemin the business sector in all regions of the world [1]. According to the data of the International Labor Organization (ILO), approximately 340 million occupational accidents occur in the world every year, and approximately 160 million people suffer from these accidents [2]. It is estimated that approximately 1.95 million people die from occupational diseases [3]. Therefore, occupational accidents appear as one of the principal factors that reduce the average human life [4]. Apart from public health, occupational accidents and illnesses also have a very significant economic cost, and it has been calculated that $5 \%$ of the world's income is spent for this reason [1].

The reporting of occupational accidents and the evaluation of them within the contexts of the economy and occupational safety are important to minimize these cases. In this regard, patients admitted to the emergency departments of hospitals due to occupational accidents are of particular importance [5].The cases of occupational accidents that are frequently encountered in emergency departments may increase due to reasons such as developments in business areas and industrialization, which increases the risks to which this patient group is exposed [5,6].Each year, a large number of workers are exposed to situations that result in permanent disability and death due to occupational accidents and illnesses [7].

The recording of occupational accidents and illnesses is one of the cornerstones for good occupational health and safety [3].In our country, sufficient studies were not carried out on occupational accidents and their detailed statistical analysis $[8,9]$.

In this study, it was aimed to determine the injury sites of the patients admitted to the Emergency Department of Kafkas University Research and Training Hospital with occupational accidents, types of injuries, and discharge/ hospitalization/mortality rates, and to analyze the demographic data of the patients.

Figure 1: Distribution of occupational accidents according to the time of day

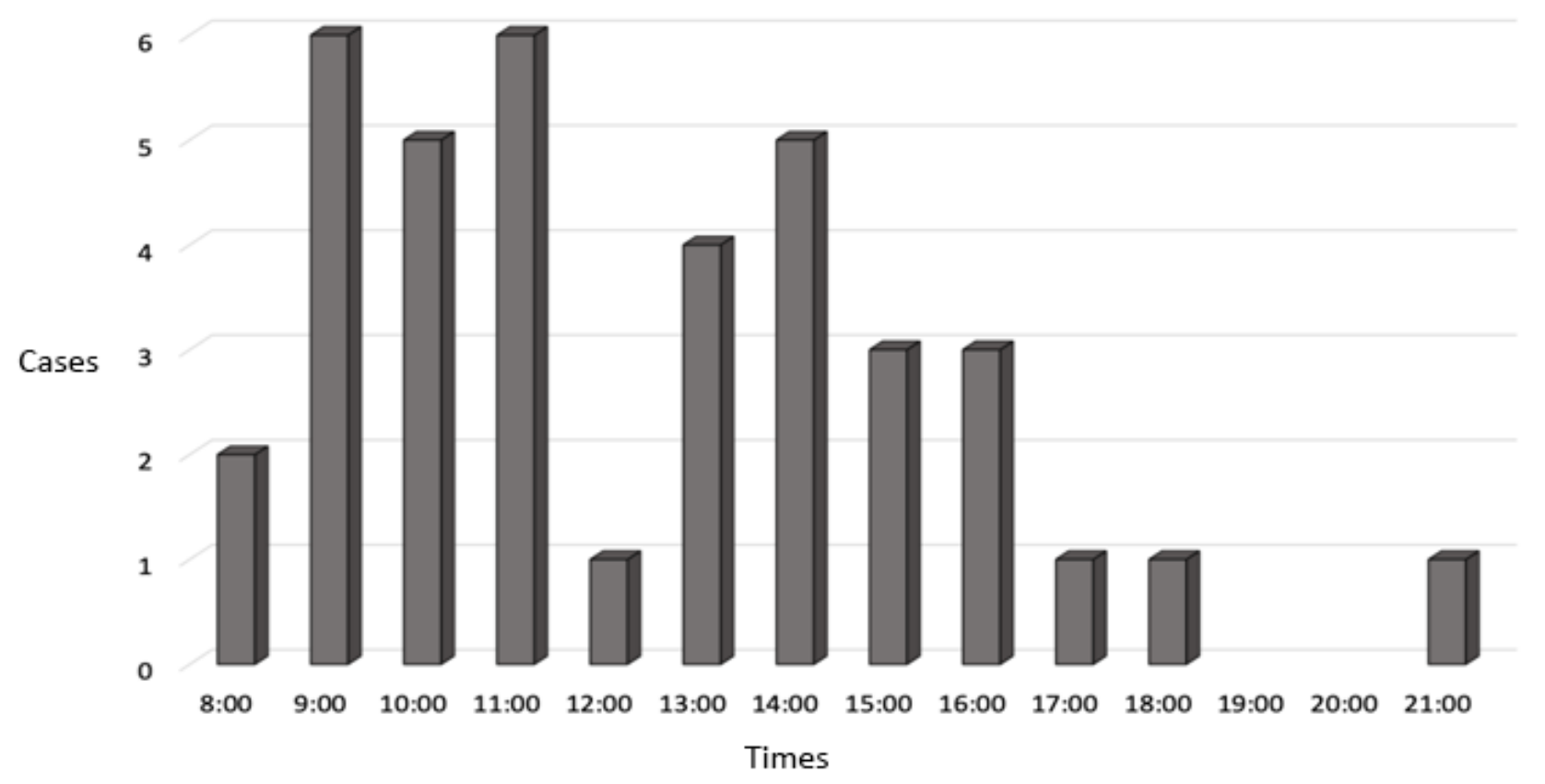


Figure 2: Distribution of occupational accidents by days

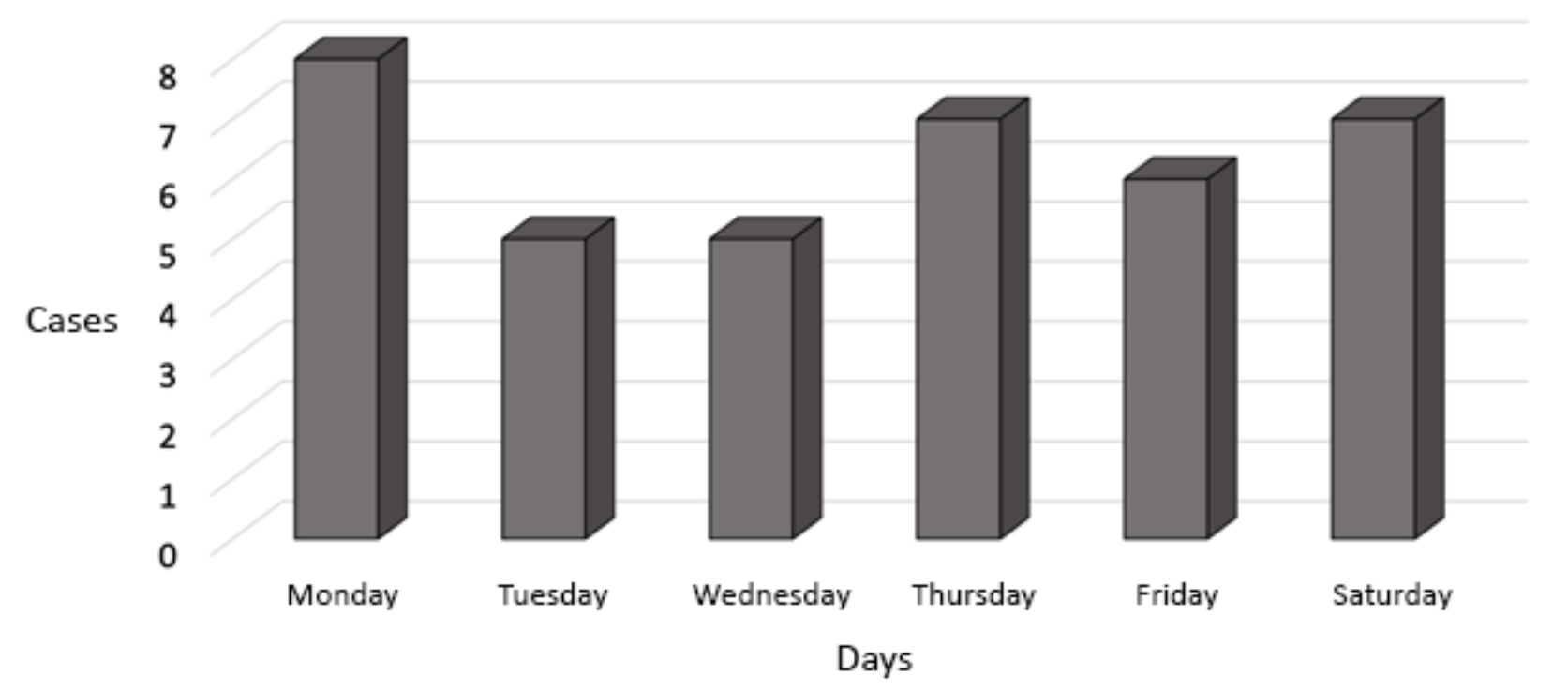

\section{MATERIALS AND METHODS}

In this study, cases of occupational accidents admitted to the Emergency Department of Kafkas University Research and Training Hospital between XX/2018-YY/2019 were retrospectively evaluated. Ethical approval was obtained from Kafkas University Health Sciences Ethics Committee before starting the study (ETHICS COMMITTEE REPORT NO:..). All occupational accident cases who were above the age of 18 and admitted to the emergency department between the specified dates were included in the study. The patients' dates and times of admission to the hospital, injury sites, discharge/ hospitalization/death status, requested consultations, and their demographic data were obtained from our hospital's HBYS system and forensic record files and included in the analyses. The data obtained were analyzed using the statistical analysis program SPSS 20.The chi-square test was used to compare frequency distributions between the groups. The significance level was considered to be $\mathrm{p}<0.05$ in experimental analyses.

\section{RESULTS}

In our study, it was observed that a total of 38 patients were admitted to the emergency department due to occupational accidents between the specified dates. The mean age of these patients was found to be $35.7 \pm 10.4$ years.It was determined that $86.8 \%$ (33 patients) and $13.2 \%$ (5 patients) of a total of 38 patients evaluated within the scope of the study were males and females, respectively. All patients were observed to have social security. There were no cases of illegal workers among the workers admitted to the emergency department.

It was determined that $40.5 \%$ of the patients had occupational accidents between 08:00-12:00. While no case was observed between 19:00 and 21:00 in the evening and at night (22:00-06:00), a serious decrease in cases was also observed during the times of day corresponding to a lunch break (Figure 1).

Among the cases between 08.00 and 12.00 which constitute the first part of the daily working hours, while 3 cases $(15.8 \%)$ were traumas that were life-threatening and 
Table 1: Distribution of injuries by anatomical regions

\begin{tabular}{lcc}
\hline Types of accident & Number & Percentage \\
\hline Abdomen & 2 & 5.26 \\
Lower Extremity & 5 & 13.16 \\
Head/ Neck & 11 & 28.95 \\
Multiple Injury & 4 & 10.53 \\
Chest/ Thorax & 5 & 13.16 \\
Upper Extremity & 11 & 28.95 \\
\hline Total & 38 & 100 \\
\hline
\end{tabular}

required hospitalization, other 16 cases (84.2\%) were found to be injuries that did not require hospitalization and could be resolved with a simple medical intervention. While $4(25 \%)$ of 16 cases admitted to the emergency department between 13:00 and 17:30, which constitute the second part of routine working hours, were also serious traumas that were life-threatening and required hospitalization, other 12 cases $(75 \%)$ were found to be injuries that did not require hospitalization and could be resolved with a simple medical intervention. No significant difference was observed between these two periods of time in terms of the frequency values of occupational accidents requiring medical intervention $(\mathrm{p}=0.49)$.

In our study, it was determined that occupational accidents mostly occurred on Monday and Saturday. It was observed that approximately $21.6 \%$ of all occupational accidents occurred on Monday, while $18.9 \%$ of them occurred on Saturday (Figure 2).

Upon investigating injury sites, it was observed that injuries of the upper extremity (28.95\%) and head/neck (28.95\%) were the most common injuries. They were followed by injuries of the lower extremity (13.16\%) and chest $(13.16 \%)$. While injuries of the abdomen (5.26\%) constituted the rarest group of occupational accidents, simultaneous injuries of multiple sites constituted $10.53 \%$ of total accidents (Table 1).

Although frequencies in the injury sites differ between the studies, head and upper extremity injuries are generally among the most common injuries $[5,10]$.

When the types of hospital admission of the patients were evaluated, it was observed that $7(18.4 \%)$ of 38 patients arrived with 112 ambulance, and 31 (81.6\%) patients arrived at the emergency department by their own means.

In our study, it was observed that 7 (18.4\%) patients were hospitalized for treatment, and 31 (81.6\%) patients were discharged after the completion of their treatment in the emergency department. A patient who was admitted to the emergency department due to the occupational accident died. In the previously reported studies, it was also observed that the vast majority of patients were discharged after necessary interventions [11]. The reason for the high rates of discharge from the emergency department is that most of the occupational accidents are injuries that can be resolved by a simple medical intervention. 


\section{DISCUSSION}

In the present study, the mean age was found to be $35.7 \pm 10.4$ years. A close mean age was found in the previously reported occupational accidents [12]. The main reason for occupational accidents to be concentrated over the age of 30 years is that workers in this age group are generally considered as masters and directed to riskier heavyduty machines since they have long-term professional experience, and thus, they face more risk.

When occupational accidents in Kars province are analyzed by gender, we consider that the relative increase in female workers is parallel to the increase in the ratio of female workers in recent studies carried out in Turkey [5].

According to the SSI (social security institution) work and occupational accident data, occupational accidents occur most frequently between 09.00-12.00 [13]. We think that the reason for the frequent occurrence of occupational accidents at these times of the day is the problem of adaptation to work and orientation failures in the first hours of work. The mortality rates in occupational accidents were $37.7 \%$ between $09.00-12.00$, and deaths were mostly observed between the hours of 16.00-17.00 at the end of working hours [14]. In the current study, the single fatal occupational accident occurred between 09.00-12.00.

When the types of hospital admission of the patients were evaluated, it was observed that 7 of 38 patients arrived with 112 ambulance, and the other 31patients arrived at the emergency department by their own means. In the study conducted by Dağlı et al., it was determined that patients who had occupational accidents were mainly transported by private vehicles [5]. We consider that workers do not receive adequate first aid training and that patients are transported by private vehicles without waiting for the ambulance since their workmates feel panic at the scene.

\section{CONCLUSION}

Occupational accidents are common in the emergency department and play an important role in mortality and morbidity. First aid and occupational accident training should be provided to workers for the prevention of accidents, which are frequent on Mondays and Saturdays and during working hours, and from the time of the accident to hospitalization. We believe that due to the widespread of head/neck and upper extremity injuries, strict inspections of workers to ensure protective measures (such as clothing, gloves, helmets) will significantly reduce occupational accidents.

\section{REFERENCES}

[1] Karadeniz O. Dünyada ve Türkiye'de iş kazaları ve meslek hastalıkları ve sosyal koruma yetersizliği. Calisma ve Toplum. 2012;34(3).

[2] Jilcha K, Kitaw D. A literature review on global occupational safety and health practice $\&$ accidents severity. International Journal for Quality Research. 2016;10(2).

[3] Hämäläinen P, Takala J, Kiat TB. Global estimates of occupational accidents and work-related illnesses 2017. World. 2017;2017:3-4.

[4] Rushton L. The global burden of occupational disease. Current environmental health reports. 2017;4 (3):340-348.

[5] Dagli B, Serinken M. Acil servise basvuran is kazalarina bagli yaralanmalar. Journal of Academic Emergency Medicine. 2012;11(3):167.

[6] Ceylan H. Türkiye'deki iş kazalarının genel görünümü ve gelişmiş ülkelerle kıyaslanması. Uluslararası Mühendislik Araştırma ve Geliştirme Dergisi. 2011;3(2):18-24.

[7] Yardım N, Çipil Z, Vardar C, Mollahaliloğlu S. Türkiye iş kazaları ve meslek hastalıkları: 2000- 
2005 yılları ölüm hızları. Dicle Tıp Dergisi. 2007;34(4):264-271.

[8] Kekeç Z, Ünalan D, Şenol V, Çetinkaya F. Erciyes üniversitesi Tip Fakültesi Acil Servisine başvuran iş kazalarının değerlendirilmesi. Fırat Üniversitesi Sağlık Bilimleri Tıp Dergisi. 2003;17:277-83.

[9] Satar S, Kekec Z, Sebe A, Sarı A. Çukurova Üniversitesi Tip Fakültesi Acil Tıp Anabilim Dalına başvuran iş kazası olgularının analizi. Çukurova Üniversitesi Tip Fakültesi Dergisi. 2004;29:11827.

[10] Güven FMK, Bütün C, Beyaztaş FY, Eren ŞH, Korkmaz İ. Cumhuriyet Üniversitesi Tıp Fakültesi Hastanesi'ne başvuran adli olguların değerlendirilmesi. 2009;

[11] Birgen N, Yavuz MS, Okyay M. İş kazası olgularının adli tıp açısından değerlendirilmesi. Journal of Forensic Medicine. 2001;15(2):14-18.

[12] Ozkan S, Kilic S, Durukan P, Akdur O, Vardar A, Geyik S, vd. Occupational injuries admitted to the Emergency Department. Ulus Travma Acil Cerrahi Derg. 2010;16(3):241-7.

[13] T.C. Sosyal Güvenlik Kurumu [Internet]. [a.yer 23 Eylül 2019]. Erişim adresi: http://www.sgk.gov.tr/ wps/portal/sgk/tr/kurumsal/istatistik/ sgk_istatistik_yilliklari

[14] Gürcanlı E. İnşaat sektöründe gerçekleşen ölüm ve yaralanmaların analizi. Mesleki Sağlık ve Güvenlik Dergisi (MSG). 2015;13(48). 